\title{
Game Based Learning as an Alternative During the Covid-19 Epidemic Based on K-13 for Indonesia Elementary Schools
}

\author{
Fresy Nugroho ${ }^{1,2, *}$, Eko Mulyanto Yuniarno ${ }^{1}$, Mochamad Hariadi ${ }^{1}$ \\ ${ }^{1}$ Department of Electrical Engineering Institut Teknologi Sepuluh Nopember Surabaya, Indonesia \\ ${ }^{2}$ Department of Information Technology, Faculty Science and Technology, Universitas Islam Negeri Maulana \\ Malik Ibrahim, Malang, Indonesia \\ *Corresponding author. Email: fresy14@mhs.ee.its.ac.id
}

\begin{abstract}
Serious-game is a new online learning approach, which is proven to increase students' knowledge and skills. During the COVID-19 period, students, especially in Indonesia, still experienced several obstacles in taking online learning using e-learning. For example, students quickly got bored. Therefore, to increase student interest in education, it is necessary to develop serious-game, with a fun element. In this study, to improve students' engagement with learning materials, we made a K-13 based serious-game. This paper describes it based on three aspects of Bloom's taxonomy and applies the activity theory model. At the validation stage, the validator consists of 20 multimedia experts, teachers, and students, respectively. In the testing phase, we tested serious-game on 60 students from elementary schools in East Java. Testing did by giving a questionnaire before playing and after playing 10, 25, and 30 times. They were testing to determine the improvement in cognitive, affective, and psychomotor students. The students' mean score during the pre-test was 58.23. After playing ten times, the students' mean score was 65.95 . After playing 25 times, the students' achievement increased to 72.54 , and after playing 30 times, the students' understanding rose to 79.61. The test results on 60 students stated that there was a significant positive increase. After playing, students' improvement proved to be balanced because the proposed design considered three aspects of Bloom's Taxonomy.
\end{abstract}

Keywords: Serious-game, K-13, Activity Theory Model, Bloom's Taxonomy

\section{INTRODUCTION}

The metamorphosis of literacy systems has enabled a new schooling paradigm known as e-learning to implement. As a result of the COVID-19 epidemic, the teaching session closure worldwide has caused 1.5 billion learners and 63 million teachers [1], [2] to change their classroom abruptly. This atmosphere revealed that schooling systems face the new challenge of ubiquitous digitalization, with their advantages and weaknesses. Berrocoso [3] points out the existing framework inadequacies and the need to access the internet universally and cheaply for education. The government should focus on the transparent and fair principles of e-learning [4].

Indonesia's e-learning research shows the lack of facilities and infrastructure and the unpreparedness of technology education [5]. Coupled with human resources, management arrangements, curriculum, and learning facilities [6], limited internet costs, limited internet quota, and slow internet [7]. From teacher perception, student learning styles tend to be visual, and teachers are less flexible in controlling student activities [8]. From the student parents' perspective, there is additional work for parents to assist their children in learning [9].

The findings of serious-game [10]:

1. Inspiring motivation [11]

2. Play is a native kind of education [12]

3. Lead cognitive stream [13]

4. Support learning-by-doing [14]

5. Enabling student's performance monitoring [3]

6. Proffer independence of movement concerning the problem [15]

7. Supporting social learning [16]

8. Allow doing experimentation safely [17]

9. Accommodate new generations of learners [18]

10. Proven success for learning [19] 
Based on the findings described above, this paper contribution is proposing online education, namely a serious-game, carried out based on the activity theory model approach, which combines the learning, game, and instructional aspects [20], [21]. It also covers the three domains of Bloom's Taxonomy [22][23]. As an initial focus, we suggest that case studies of the science material used are Natural Science material, earth, and space sub-chapters for $4^{\text {th }}$-grade elementary schools in Indonesia.

\section{STATE OF THE ART}

In this section, the latest developments that underlie this research describe. It consists of three main pillars, namely a serious-game description, given the rapid growth of digital technology, followed by a seriousgame model that focuses on the game mechanics side. Finally, the application of Bloom's Taxonomy in the elearning sector also present.

\subsection{Serious Game}

Serious-game has reached an exciting point of development because serious-game can balance the functions of education, training facilities, and entertainment at the same time. Thus, it is a breakthrough to support effective and efficient learning [24]-[26].

The new approach proposed by serious-game considers the dynamics of the game players' actions and the players' motivation based on the game flow theory [27][28]. The research results have proven based on quantitative research by performing seven simulations and involving 100,000 iterations to establish the proposed model's stability. With this approach, it is possible to show the relationship between game variables and how the serious-game learning process can design a serious-game [26].

\subsection{Activity Theory Model in Serious Game}

This study completes several frameworks that have developed previously, namely the serious-game based on service-oriented architecture. The activity theory model-based framework outlines in detail down to a serious-game mechanic level shown in Figure 1. The proposed approach is evaluated using the architectural trade-off analysis method and applies to the seriousgame. Serious-game design results can involve education and entertainment elements balance in portion and fast production time. The next effect is a reduction in production costs and an increase in serious-game quality. Where this model has main activities, namely: play, learning, and instructional activities. Each exercise consists of three components, namely: action, device, and goal [20], [21], [24].

\subsection{Bloom's Taxonomy}

Bloom's Taxonomy consists of knowledge, understanding, application, analysis, synthesis, and evaluation. Furthermore, the Bloom Taxonomy has revised by adding several components, such as changing terms at each level, setting a more detailed stage, and adding the dimensions. This change applied to elearning designs that contain online instruction. Elearning is object-based and learning outputs. The example proposed as an application is about learning grammar. Where the proposed method has considered three aspects of integrated learning, namely cognitive, affective and psychomotor aspects of the player [22], [23].

\subsection{National Curriculum 13 (K-13)}

The 2013 national curriculum (K-13) is a development of the existing curriculum, namely the Competency-Based Curriculum and the Education Unit Level Curriculum, which applied in 2014/2015. The K13 emphasizes improving and balancing soft skills and hard skills, including competence in attitudes, knowledge, and agility. The position of competence, originally derived from the subject, turned into an issue developed from competence. The characteristics that differentiate it from previous curricula are as follows: the approach used in learning is scientific and integrated thematic, attitudes, competence, skills, knowledge, using authentic assessment. An accurate estimate is an assessment carried out, including student preparation, the learning process, and student learning outcomes. The learning methods used are lectures, discussions, questions, and answers, conducting experiments, solving problems, and modeling [29].

\section{METHOD}

The research procedure is built in five stages, as shown in Figure 2, including:

1. Identification of $\mathrm{K}-13$, science material for $4^{\text {th }}$-grade Elementary School. The curriculum involves three domains of Bloom's Taxonomy, consisting of cognitive, affective, and psychomotor domains. Table 1 presents the types of $4^{\text {th }}$-grade Elementary School in science competencies. Competence can be divided into two types, competency standards and basic competencies. Competency standards consist of a) understanding the transformation of earth and space, $b$ ) understanding the change of the region and its effects on the surrounding area and c) understanding the association between the natural resources of the universe and the surrounding area. Competency standards (a) taught in the $1^{\text {st }}$-semester, competency standards (b), and (c) are given in the $2^{\text {nd }}$-semester. Identification of students' understanding in the $4^{\text {th }}$-grade science field to determine the 


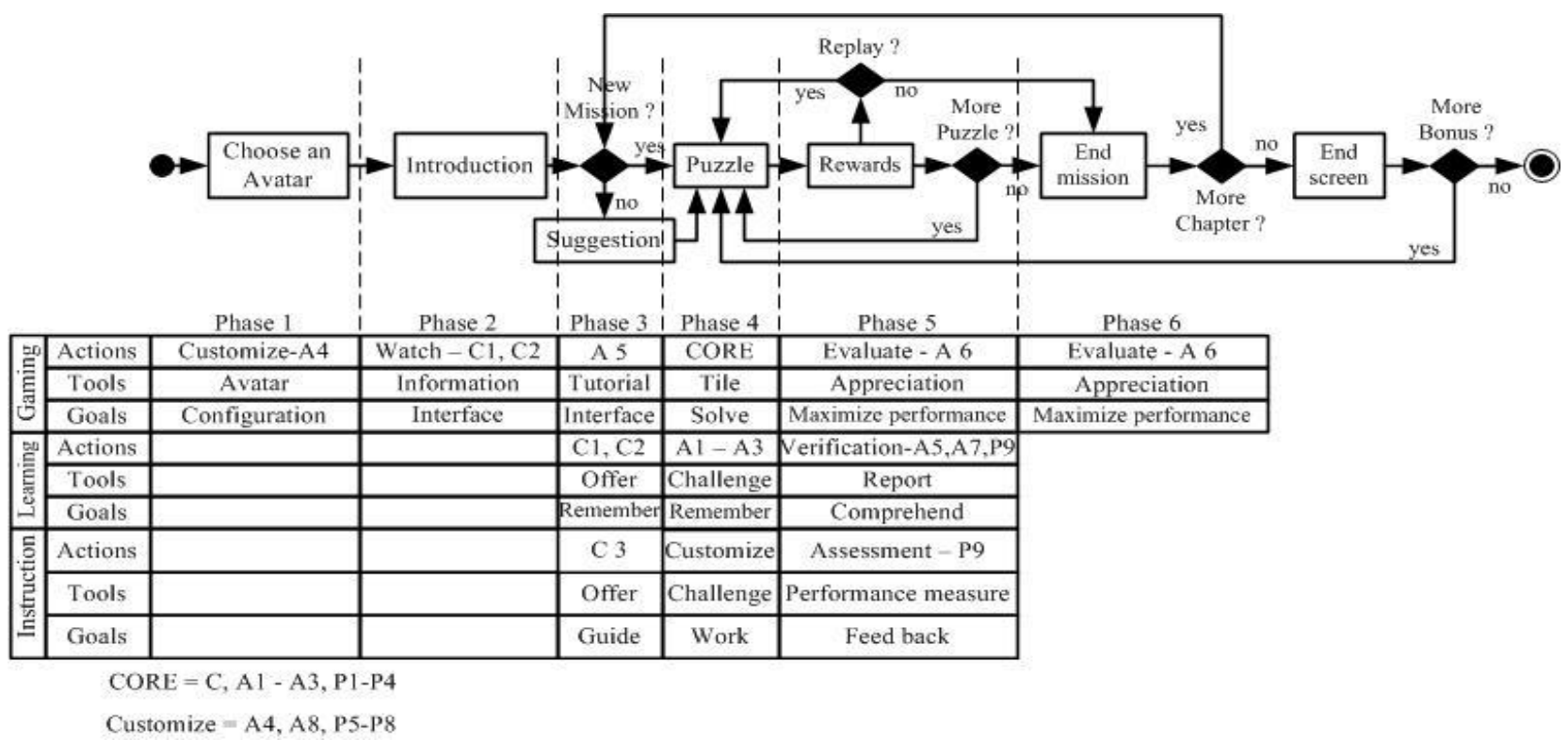

Figure 1 The identification of K-13 to serious-game

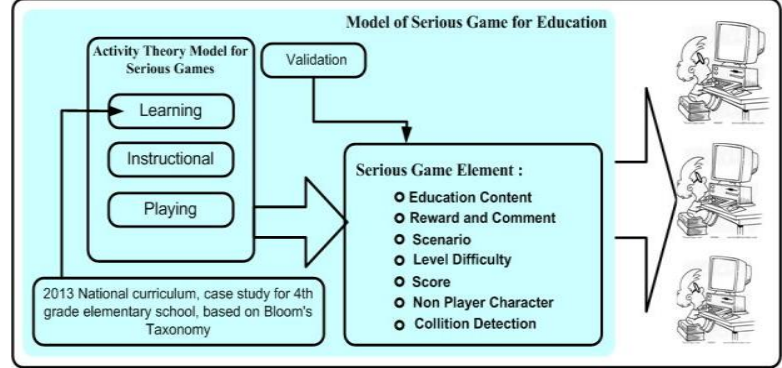

Figure 2 The proposed research block diagram

level of mastery of students in terms of cognitive aspects, including memory levels $\left(\boldsymbol{C}_{\boldsymbol{1}}\right)$, knowledge $\left(\boldsymbol{C}_{2}\right.$, and application $\left(\boldsymbol{C}_{3}\right)$. Meanwhile, to find out the level of understanding of students in the affective domain, including curious behaviour $\left(\boldsymbol{A}_{\mathbf{1}}\right)$, getting something new $\left(\boldsymbol{A}_{2}\right)$, collaboration $\left(\boldsymbol{A}_{3}\right)$, never giving up $\left(\boldsymbol{A}_{\mathbf{4}}\right)$, asking if finding difficulties $\left(\boldsymbol{A}_{\mathbf{5}}\right)$, introspection $\left(\boldsymbol{A}_{\mathbf{6}}\right)$, be consistent $\left(\boldsymbol{A}_{\mathbf{7}}\right)$, dare to express opinions $\left(\boldsymbol{A}_{\mathbf{8}}\right)$, and discipline $\left(\boldsymbol{A}_{\mathbf{9}}\right)$. Then to find out the level of understanding of students in the psychomotor aspect described as the ability to observe $\left(\boldsymbol{P}_{\mathbf{1}}\right)$, be thorough and regular $\left(\boldsymbol{P}_{\mathbf{2}}\right)$, classify $\left(\boldsymbol{P}_{3}\right)$, estimate $\left(\boldsymbol{P}_{4}\right)$, design $\left(\boldsymbol{P}_{5}\right)$, carry out research $\left(\boldsymbol{P}_{\mathbf{6}}\right)$, summarize $\left(\boldsymbol{P}_{\mathbf{7}}\right)$, implement $\left(\boldsymbol{P}_{\mathbf{8}}\right)$, and socialization $\left(\boldsymbol{P}_{\mathbf{9}}\right)$. The description of indicators for each student competency standard is shown in Table 2.

2. Identify the activity theory model when playing games. The activity theory model is used to compile the gameplay of the serious-game created shown in Figure 1 .

Table 1. Elaboration of $4^{\text {th }}$-grade elementary school science competencies

\begin{tabular}{|l|l|}
\hline \multicolumn{1}{|c|}{ Competency standards } & \multicolumn{1}{c|}{ Basic competencies } \\
\hline $\begin{array}{l}\text { a. understanding the } \\
\text { transformation of earth and } \\
\text { space }\end{array}$ & $\begin{array}{l}\text { 1. Describe the transformation of the earth's surface } \\
\text { 2. Describe the appearance of the planet each day and the position of the moon }\end{array}$ \\
\hline $\begin{array}{l}\text { b. understanding the change } \\
\text { of the region and its effects } \\
\text { on the surrounding area }\end{array}$ & $\begin{array}{l}\text { 1. Explain the causes of environmental transformation } \\
\text { 2. Describe the effect of environmental change on the earth }\end{array}$ \\
\hline $\begin{array}{l}\text { c. Tells how to prevent environmental damage } \\
\text { association between the } \\
\text { natural resources of the } \\
\text { universe and the } \\
\text { surrounding area. }\end{array}$ & $\begin{array}{l}\text { 1. Describe the association between universal resources and the surrounding area } \\
\text { 2. Formulate the association between adaptable resources and technology }\end{array}$ \\
\hline
\end{tabular}


Table 2. Learning identification based on Bloom's Taxonomy

\begin{tabular}{|c|c|c|c|c|}
\hline \multicolumn{2}{|c|}{ Learning indicators in the serious-game } & \multirow{2}{*}{$\begin{array}{c}\text { Cognitive } \\
\text { (30\%) } \\
C_{1}\end{array}$} & \multirow{2}{*}{$\begin{array}{l}\text { Affective } \\
\text { (30\%) }\end{array}$} & \multirow{2}{*}{$\begin{array}{c}\text { Psychomotor } \\
(40 \%)\end{array}$} \\
\hline 1 & Identify the transformation of the earth's surface & & & \\
\hline 2 & Identification of the appearance of the planet each day & $C_{1}$ & & \\
\hline 3 & Explain the causes of environmental transformation & $C_{2}$ & & \\
\hline 4 & Describe the effect of environmental change on the earth & $C_{2}$ & & \\
\hline 5 & Tells how to prevent environmental damage & $C_{2}$ & & \\
\hline 6 & $\begin{array}{l}\text { Describe the association between universal resources and the } \\
\text { surrounding area }\end{array}$ & $C_{3}$ & & \\
\hline 7 & Repeating the experiment & & $A_{1}$ & \\
\hline 8 & Get involved in assignments & & $A_{2}$ & \\
\hline 9 & Help each other in simulation & & $A_{3}$ & \\
\hline 10 & Free thinking & & $A_{4}$ & \\
\hline 11 & Ask questions if you're having trouble & & $A_{5}$ & \\
\hline 12 & Learning indicators in the serious-game & & $A_{6}$ & \\
\hline 13 & The consequences & & $A_{7}$ & \\
\hline 14 & Implement a safe experiment & & $A_{8}$ & \\
\hline 15 & Complete question and assignment sheets & & & $P_{1}$ \\
\hline 16 & Discipline & & & $P_{2}$ \\
\hline 17 & Separating types of environmental transformation & & & $P_{3}$ \\
\hline 18 & Crafting environmental change on the earth puzzles & & & $P_{4}$ \\
\hline 19 & Estimating the possible transformations during the experiment & & & $P_{5}$ \\
\hline 20 & Planning a simulation to reduce the impact of a disaster & & & $P_{6}$ \\
\hline 21 & $\begin{array}{l}\text { Planning the impact of natural exploitation on world conservation } \\
\text { simulation experiment }\end{array}$ & & & $P_{7}$ \\
\hline 22 & $\begin{array}{l}\text { Carry out miniature natural exploitation on world conservation } \\
\text { experiments }\end{array}$ & & & $P_{8}$ \\
\hline 23 & Presenting the results of environmental damage simulation & & & $P_{9}$ \\
\hline
\end{tabular}

3. Validation of the serious-game beta version. The validator consists of multimedia experts, teachers, and students. Multimedia experts aim to validate from the multimedia side, among others: Ease of information, ease of play, layout, fonts used, colours, and navigation. The principal and 1 st carried out validation in terms of learning materials to 4th-grade elementary school teachers. Validation based on the user side was carried out by ten randomly selected students. The student validation component focuses on comfort while playing, pleasing students, interest in games, material, and quickly capturing tasks to be completed.

4. Testing on $4^{\text {th }}$-grade students. A total of 60 elementary school students in East Java became respondents for the next test. Respondents were 34 male students and 26 female students. They test ten times, 25 times, and 30 games.

\section{RESULT AND DISCUSSION}

In the learning process, students will go through three phases or three processes during learning. The first stage is the cognitive phase, which is when students get material from a teacher. Students get information about what, why, and how to do the movement activities to be studied in this phase. It hoped that a motor-plan formed in students' minds, namely intellectual skills, in planning how to perform skills. The second stage is the associative or fixation phase, which is where students will exercise from the material taught in the cognitive setting [30]. At this stage of the exercise, students can do or apply the material taught as shown in Figure 3. 


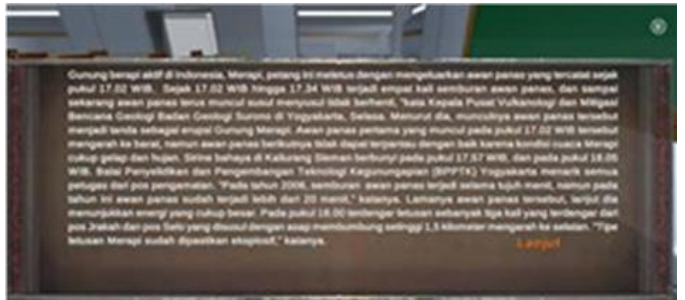

a

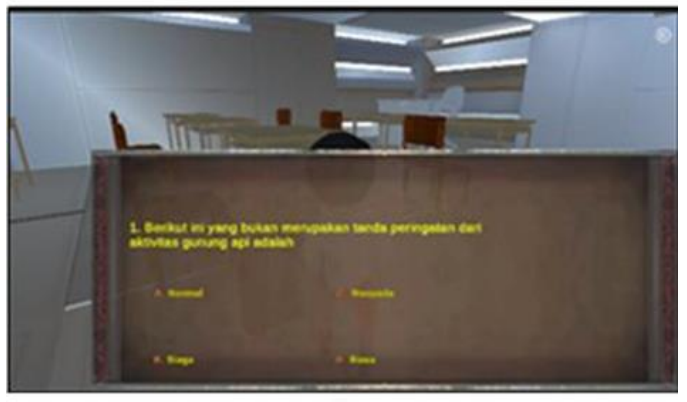

$\mathrm{b}$

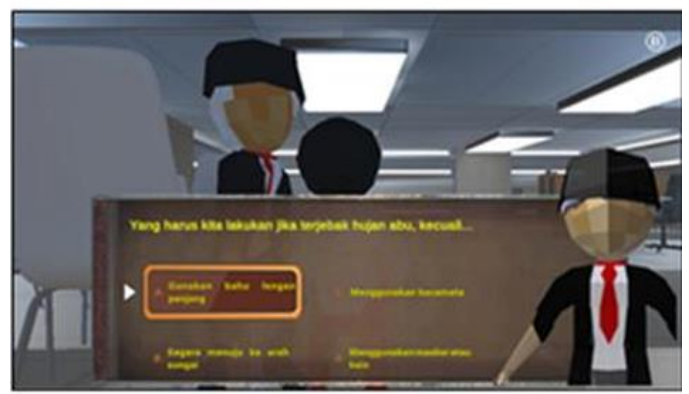

$\mathrm{c}$

Figure 3. This is an example of a serious game proposed. Where (a) is information that students must know, then (b) shows an example of a question related to the previous material description (a). Then, (c) students answer the question, the student's answer shows.

As mentioned in point 4 , the serious-game validation was performed by 20 multimedia experts, 20 teachers, and 20 random students from 1 st to $4^{\text {th }}$-grade elementary school shown in Figure 4. The multimedia experts, giving a score of 70 to 80 . It means the serious-game is proper to use. In terms of learning materials, the scores obtained are 70 to 80 . This score shows that the questions raised in the serious-game have met the K-13 standards and have covered the three domains of Bloom's Taxonomy for grade 4 SD students. Validation from students, giving a score of 75 to 80 . This score shows that this serious-game provides comfort, fun, and ease of play.

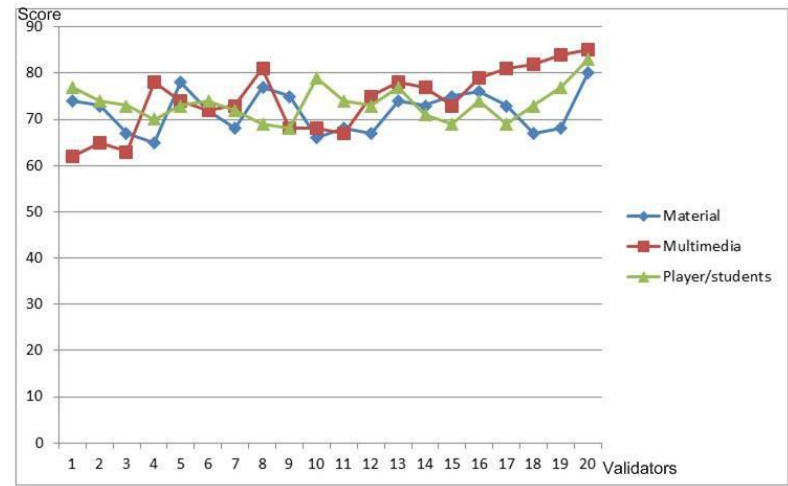

Figure 4. Serious-Game Validation Results

The pre-test and post-test on 60 students shown in Figure 4 , the $\mathrm{x}$-axis is the number of students, and the $\mathrm{y}$ axis is the score achieved by students with a value range of 0 to 100. The experiment consists of three stages: pre-test, post-test after playing ten times, post-test after 25 times play, and the post-test after playing 30 times. The questionnaire during the pre-test and post-test after playing consisted of 20 questions. A pre-test uses to find out students' understanding of science material before playing a serious-game. The post-test to determine student understanding was carried out three times, namely after playing ten times, 25 times, and after playing 30 times. In Figure 5, there is an increase in the score of each student.

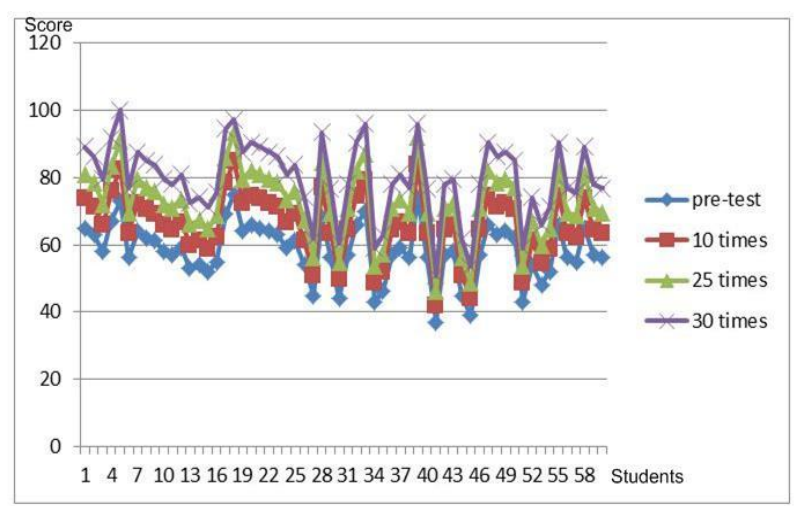

Figure 5. The results of the pre-test and post-test of 60 students

The students' mean score during the pre-test was 58.23. After playing ten times, the students' mean score was 65.95. After playing 25 times, the students' achievement increased to 72.54 , and after playing 30 times, the students' understanding rose to 79.61. This score states that students enjoy the games, and students have increased the mastery of the learning material presented. The achievement of the average student score shows in Figure 6. 


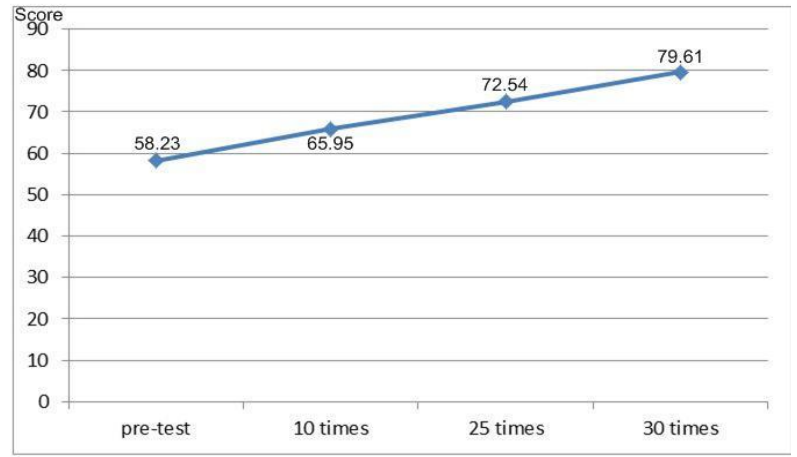

Figure 6. Improved student understanding scores

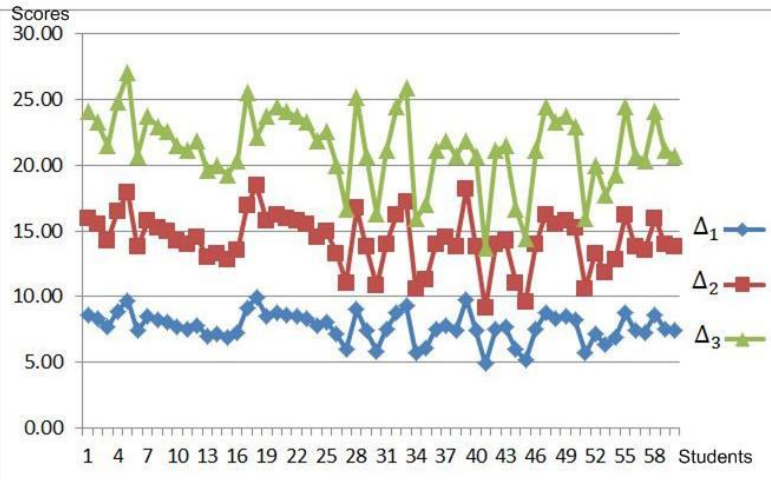

Figure 7. The difference in students' understanding scores

The increase in knowledge of each student view as a difference. This difference shows in Figure 7. The rise in student know-how after playing ten times state as $\Delta 1$, the increase in student scores after playing 25 times label as $\Delta 2$, and student scores after playing 30 times express as $\Delta 3$. The $\mathrm{x}$-axis represents the number of students, and the $y$-axis is the score achieved by students. The students' average ability $\Delta 1$ increased by $7.71 \%$ after playing ten times compared to the pre-test scores from this difference in scores. In 2, after the students played 25 times, the students' average understanding increased by $14.31 \%$ compared to the pre-test score. Furthermore, in 3, after the students played 30 times, the students' knowledge increased by $21.38 \%$ compared to the pre-test score.

Assessment based on each side of learning, which is the cognitive aspects of $30 \%, 30 \%$ the affective, and $40 \%$ the psychomotor, was carried out by recording each student's performance. Following the description of Table 2, if the student answers correctly, then the student gets one point. If the student answers incorrectly, then his/her score is zero. The cognitive aspect's maximum points are six because the questions asked consist of six indicators students', namely $\mathrm{C} 1$ with two indicators, C2 consist of three indexes, and C3 with

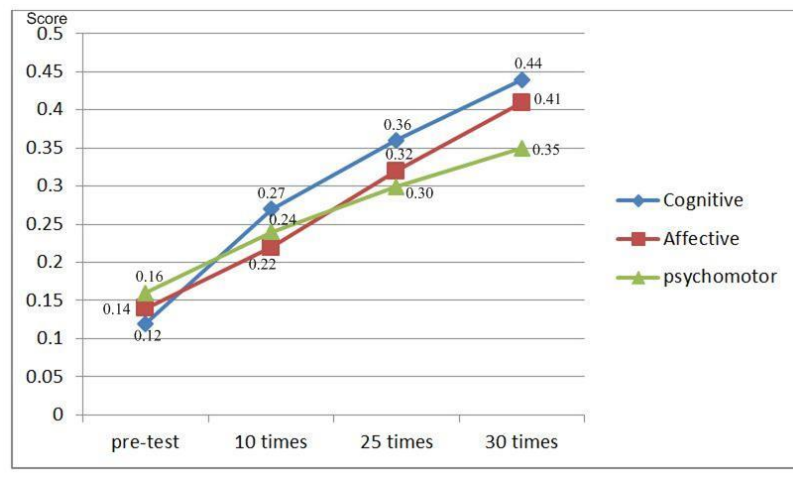

Figure 8. The students' achievement of cognitive, affective and psychomotor aspects

one scale. On the affective side, students' maximum points are 8 points, consisting of A1 to A8.

Meanwhile, on the psychomotor side, the maximum score a student can achieve is 9 points consisting of P1 to P9. Figure 8 shows the increase in students' performance at the pre-test after playing ten times, 25 times, and 30 times. From the cognitive side, during the pre-test, students' mean score was 0.12 ; after playing ten times, the score went up to 0.27 , then after playing 25 times, the score became 0.36; after playing 30 times increased sharply to 0.44 . This score shows that on the cognitive side, the performance is a significant positive increase. From the affective side, during the pre-test, the mean score was 0.14 ; after playing ten times, the score became 0.22 ; after playing 25 times, the student score became 0.32 ; after 30 times, they developed to 0.41 . The affective side is also experiencing positive developments. From a psychomotor perspective, during the pre-test, the mean score achieved was 0.16; After playing ten times, the mean score of students crept to 0.24 , then after playing 25 times, the mean score of students spread to 0.30; after playing 30 times also boosted to 0.35 . This condition states that the skills of the students have improved significantly.

The minimum learning completeness standard is that students achieve a value of $\geq 75$. The number of students who attain the classical completeness criteria is $\geq 85 \%$ of the students' total number. In this study, we compared the number of students who managed to meet the mastery learning standards after learning using elearning [1] and the serious-game. The test was three times on each media. In e-learning, it is named precycle, cycle one, and cycle 2 . Whereas in the seriousgame it is called pre-play, playing ten times and playing 25 times. 
Table 3. The comparison between e-learning and serious-game

\begin{tabular}{|c|c|c|c|}
\hline \multicolumn{4}{|c|}{ e-learning } \\
\hline Cycle & Category & Sum & Percentage \\
\hline \multirow[t]{2}{*}{ pre-cycle } & Completed & 14 & 48.3 \\
\hline & $\begin{array}{l}\text { Not } \\
\text { Completed }\end{array}$ & 15 & 51.7 \\
\hline \multirow[t]{2}{*}{ Cycle I } & Completed & 24 & 82.8 \\
\hline & $\begin{array}{l}\text { Not } \\
\text { Completed }\end{array}$ & 5 & 17.2 \\
\hline \multirow[t]{2}{*}{ Cycle II } & Completed & 26 & 89.7 \\
\hline & $\begin{array}{l}\text { Not } \\
\text { Completed }\end{array}$ & 3 & 10.3 \\
\hline \multicolumn{4}{|c|}{ Serious-game } \\
\hline \multirow[t]{2}{*}{ Pre-play } & Completed & 12 & 41.38 \\
\hline & $\begin{array}{l}\text { Not } \\
\text { Completed }\end{array}$ & 17 & 58.6 \\
\hline \multirow{2}{*}{$\begin{array}{l}10 \text { times } \\
\text { play }\end{array}$} & Completed & 25 & 86.21 \\
\hline & $\begin{array}{l}\text { Not } \\
\text { Completed }\end{array}$ & 4 & 13.79 \\
\hline \multirow{2}{*}{$\begin{array}{l}25 \text { times } \\
\text { play }\end{array}$} & Completed & 27 & 93.10 \\
\hline & $\begin{array}{l}\text { Not } \\
\text { Completed }\end{array}$ & 2 & 6.89 \\
\hline
\end{tabular}

In e-learning, Table 3 shows that the pre-cycle learning outcomes are 14 students (48.3\%) completeness and 15 students $(51.7 \%)$ incomplete. These results do not meet the predetermined completeness criteria, so they continue to cycle I. In the learning outcomes of a cycle I, 24 students $(82.8 \%)$ complete, and five students (17.2\%) are incomplete, with the percentage of classical completeness, only $82.8 \%$. These results do not meet the predetermined completeness criteria, so their research continues to cycle II. In the second cycle, classically, students who get a score bigger than 75 (the amount of teaching and learning activities) reach $89.7 \%$ of the total students. The percentage of results has surpassed the entire students' classical completeness criteria to complete their studies [31].

While the learning outcomes using the serious-game, before playing, were 12 students $(41.38 \%)$ completed, and 17 students $(58.6 \%)$ did not complete. These results do not meet the predetermined completeness criteria, so students continue to play ten times. After students played ten times in the learning outcomes, 25 students (86.21\%) completed, and four students $(13.79 \%)$ did not complete, with the percentage of classical completeness reaching $86.21 \%$. The rate of results has matched the classical completeness criteria, namely $\geq 85 \%$ of the total students. After playing 25 times, it confirmed that the classical completeness criteria reached $93.10 \%$.

From these comparisons, it appears that the use of serious-games increases the achievement of the minimum learning completeness standards that must fulfil and the classical completeness criteria.

\section{CONCLUSION}

From the description of the results and the previous discussion, several conclusions can be drawn, such as the validation by multimedia experts, teachers, and students shows that the serious- game has fulfilled the educational and entertainment side. The test results on 60 students stated that there was a significant positive increase. After playing, students' improvement proved to be balanced because the proposed design considered three aspects of Bloom's Taxonomy.

However, the results still show some weaknesses. The weakness assumes it is the education material side. Most of the question is multiple choice with one correct answer only. Thus, it may boredom the player. There is also the possibility that while playing, students give solutions that are not intentionally correct, or the answers given are the result of a friend's solution rather than the student's thought. The appearance of the questions is still static, so students easily memorize them. The game scenario is still passive, so it is possible for students to get bored quickly. Changes in-game difficulty has not been explored more deeply, so players can quickly master the game soon. The number of respondents used is still small, so there is always a possibility that the types of students who play are homogeneous.

From the observation of these weaknesses, further, development can focus on several points. For example, the questions posed would be better if more than one correct answer develops students' abilities. The problem is present by increasing the number of items for the same outcome indicator to avoid answering the right answer inadvertently. The static problems were replaced by applying artificial intelligence to the question generator to adapt to students' abilities. Game scenarios need to add with autonomous scenario generators. Changes in-game difficulty also needs to be made more diverse and made different at the beginning of each game; this can be done by embedding machine learning in the serious game to hope that players will always feel challenged. Increasing the number of respondents from different primary schools can provide diversity in the types of students.

\section{REFERENCES}

[1] World Bank, "The COVID-19 Pandemic: Shocks to Education and Policy Responses," World Bank 
Gr., no. May 2020, p. 49, 2020, doi: 10.12968/bjon.2020.29.8.456.

[2] UNESCO, "UNESCO Covid-19 Education Response," UNESCO, United Nations Educ. Sci. Cult. Organ., pp. 1-6, 2020.

[3] J. Valverde-Berrocoso, M. del Carmen GarridoArroyo, C. Burgos-Videla, and M. B. MoralesCevallos, "Trends in educational research about eLearning: A systematic literature review (20092018)," Sustain., vol. 12, no. 12, 2020, doi: 10.3390/su12125153.

[4] V. Esteban and M. Le, "Analysis of Interpersonal Competences in the Use of ICT in the Spanish University Context," Sustainability, vol. 12, p. 476, 2020.

[5] B. Dwi, A. Amelia, U. Hasanah, and A. M. Putra, "Analysis of the Effectiveness of Online Learning during the Covid-19 Pandemic-'Analisis Keefektifan Pembelajaran Online di Masa Pandemi Covid-19,"' J. Pendidik. Guru Sekol. Dasar, vol. 2, no. 1, pp. 28-37, 2020.

[6] F. N. Arifa, "Challenges of Implementing a Home Learning Policy in a Covid-19 Emergency'Tantangan Pelaksanaan Kebijakan Belajar Dari Rumah Dalam Masa Darurat Covid-19,"' Info Singkat;Kajian Singk. Terhadap Isu Aktual Dan Strateg., vol. XII, no. 7/I, p. 6, 2020.

[7] Z. Abidin, Rumansyah, and K. Arizona, "ProjectBased Online Learning is One of the Solutions for Teaching and Learning Activities in the Middle of the Covid-19 Pandemic-'Pembelajaran Online Berbasis Proyek Salah Satu Solusi Kegiatan Belajar Mengajar Di Tengah Pandemi Covid-19,'” J. Ilm. Profesi Pendidik., vol. 5, no. 1, pp. 64-70, 2020, doi: 10.29303/JIPP.V5I1.111.

[8] A. Prima Satrianingrum and I. Prasetyo, "Persepsi Guru Dampak Pandemi Covid-19 terhadap Pelaksanaan Pembelajaran Daring di PAUD," $J$. Pendidik. Anak Usia Dini, vol. 5, no. 1, pp. 633640, 2021, doi: 10.31004/obsesi.v5i1.574.

[9] R. S. P. Agus Purwanto, Rudy Pramono, Masduki Asbari, Priyono Budi Santoso, Laksmi Mayesti Wijayanti, Choi Chi Hyun, "Exploratory Study of the Impact of the COVID-19 Pandemic on Online Learning Process in Primary Schools-'Studi Eksploratif Dampak Pandemi COVID-19 Terhadap Proses Pembelajaran Online di Sekolah Dasar," EduPsyCouns J., vol. 2, no. 1, pp. 165170, 2017.

[10] L. Van der Lubbe, C. Gerritsen, and T. Bosse, "A serious game to improve the verbal resilience against doorstep scams," Int. J. Serious Games, vol. 7, no. 2, pp. 89-119, 2020, doi: 10.17083/ijsg.v7i2.350.

[11] D. Charsky, "From edutainment to serious games: A change in the use of game characteristics," Games Cult., vol. 5, no. 2, pp. 177-198, 2010.

[12] M. A. Khenissi, F. Essalmi, and M. Jemni, "Comparison Between Serious Games and Learning Version of Existing Games," Procedia -
Soc. Behav. Sci., vol. 191, pp. 487-494, 2015.

[13] C. Zhang, K. P. Härenstam, S. Meijer, and A. S. Darwich, "Serious Gaming of Logistics Management in Pediatric Emergency Medicine," Int. J. Serious Games, vol. 7, no. 1, pp. 47-77, 2020, doi: 10.17083/ijsg.v7i1.334.

[14] Y. Zhonggen, "A Meta-Analysis of Use of Serious Games in Education over a Decade," Int. J. Comput. Games Technol., vol. 12, no. 1, pp. 3643, 2020, doi: 10.1155/2019/4797032.

[15] P. Backlund and M. Hendrix, "Educational games - Are they worth the Effort?: A literature survey of the effectiveness of serious games," in 5th International Conference on Games and Virtual Worlds for Serious Applications, VS-GAMES 2013, 2013, no. November 2015, doi: 10.1109/VSGAMES.2013.6624226.

[16] H. Ning, R. Li, X. Ye, Y. Zhang, and L. Liu, “A Review on Serious Games for Dementia Care in Ageing Societies," IEEE J. Transl. Eng. Heal. Med., vol. 8, no. May, 2020, doi: 10.1109/JTEHM.2020.2998055.

[17] L. Shoukry and S. Göbel, "Realizing a Mobile Multimodal Platform for Serious Games Analytics," Int. J. Serious Games, vol. 6, no. 4, pp. 19-48, 2019, doi: 10.17083/ijsg.v6i4.323.

[18] H. Ben Rebah and R. Ben Slama, "The educational effectiveness of serious games," no. November, 2019.

[19] M. Kickmeier-Rust and A. Holzinger, "Interactive Ant Colony Optimization to Support Adaptation in Serious Games," Int. J. Serious Games, vol. 6, no. 3, pp. 37-50, 2019, doi: 10.17083/ijsg.v6i3.308.

[20] M. B. Carvalho, "Serious Games for Learning: A model and a reference architecture for efficient game development," Universita Degli Studi Di Genova Technische Universiteit Eindhoven, 2017.

[21] M. Callaghan, N. McShane, A. G. Eguíluz, and M. Savin-Baden, "Extending the Activity Theory Based Model for Serious Games Design in Engineering to Integrate Analytics," Int. J. Eng. Pedagog., vol. 8, no. 1, p. 109, 2018, doi: 10.3991/ijep.v8i1.8087.

[22] P. Haring, H. Warmelink, M. Valente, and C. Roth, "Using the Revised Bloom Taxonomy to Analyze Psychotherapeutic Games," Int. J. Comput. Games Technol., vol. 2018, pp. 1-9, 2018, doi: 10.1155/2018/8784750.

[23] T. S. A. Syed Ahmad and A. A. Hussin, "Application of the Bloom' $\square{ }^{\mathbf{T M}_{\mathrm{S}}}$ Taxonomy in Online Instructional Games," Int. J. Acad. Res. Bus. Soc. Sci., vol. 7, no. 4, 2017, doi: 10.6007/ijarbss/v7-i4/2910.

[24] M. B. Carvalho et al., "An activity theory-based model for serious games analysis and conceptual design," Comput. Educ., vol. 87, no. July 2018, pp. 166-181, 2015, doi: 10.1016/j.compedu.2015.03.023.

[25] L. Hanes and R. Stone, "A model of heritage content to support the design and analysis of video 
games for history education," J. Comput. Educ., Sep. 2018, doi: 10.1007/s40692-018-0120-2.

[26] Z. Gao, D. Ma, X. Guo, W. Wang, and Z. Wang, "The Comprehensive Assessment Method of Concrete Damage after Disastrous Fire Based on Game Theory-Normal Cloud Model," Math. Probl. Eng., vol. 2019, pp. 1-9, 2019, doi: 10.1155/2019/5159497.

[27] M. Csikszentmihalyi, Flow: The Psychology of Optimal Experience. New York, NY: Harper Perennial, 1991.

[28] Y. Mao, S. Roberts, S. Pagliaro, M. Csikszentmihalyi, and M. Bonaiuto, "Optimal Experience and Optimal Identity: A Multinational Study of the Associations Between Flow and
Social Identity," Front. Psychol., vol. 7, 2016, doi: 10.3389/fpsyg.2016.00067.

[29] I. Kurniasih and B. Sani, "2013 Curriculum Implementation Concepts and Applications," 2014.

[30] H. Alomyan and D. Green, "Learning Theories," no. January 2012, 2012, pp. 126-130.

[31] A. R. N. Ramadhani, "Improving Science Learning Outcomes through the E-Learning Model with Video Media for 4th grade Elementary Students of MIN 4 Sukoharjo in Academic Year 2019/2020-"Peningkatan Hasil Belajar Ipa Melalui Model E-Learning Dengan Media Video pada Siswa Kelas I,” 2020. 